\title{
Urinary tract infection and oral penicillin $\mathrm{G}$
}

\author{
J. HULBERT
}

From the Department of Bacteriology, University of Dundee

SYNOPSIS The urinary excretion of three oral preparations of penicillin $G$ was measured in six subjects. After a dose of $500 \mathrm{mg}$ of potassium penicillin $\mathrm{G}$ the mean urine level was $597 \mu \mathrm{g} / \mathrm{ml}$ in the first of three two-hour periods, $324 \mu \mathrm{g} / \mathrm{ml}$ in the second, and $40 \mu \mathrm{g} / \mathrm{ml}$ between the fourth and sixth hours. Of the dose, $13.4 \%$ was excreted in the urine in 24 hours. Differences among the three preparations were not significant therapeutically.

Most Gram-negative urinary pathogens are sensitive to $5-50 \mu \mathrm{g}$ of penicillin $\mathrm{G}$ per $\mathrm{ml}$.

There is a rational basis for the use of oral penicillin $\mathbf{G}$ to treat urinary infection due to Gramnegative bacilli.

About $15 \%$ of an oral dose of penicillin $\mathrm{G}$ is absorbed, and about $80 \%$ of this is excreted in the urine. Individual variability in the amount absorbed is considerable, but this can be greatly reduced by taking the drug half an hour before meals. Acid protective agents do not improve absorption (Finland, Meads, and Ory, 1945; Mcdermott, Bunn, Benoit, DuBois, and Reynolds, 1946; Wright, Kirschbaum, Arret, Putnam, and Welch, 1955).

In a careful search of the literature only one paper could be found in which measured concentrations of penicillin in urine after oral therapy were recorded. Peeney (1947) administered 90,000 Oxford units of penicillin to a subject and found 42 units $/ \mathrm{ml}$ in the urine after one hour and 22 units $/ \mathrm{ml}$ after three hours. No information about urine volume or bladder voiding was noted. However, if $10 \%$ of an oral dose of $500 \mathrm{mg}$ of penicillin is excreted in the urine in six hours, then a patient passing $1,200 \mathrm{ml}$ of urine per day would have a mean concentration of $160 \mu \mathrm{g}$ of penicillin per $\mathrm{ml}$ of urine.

Most strains of Escherichia coli are sensitive to 12.5-50 $\mu \mathrm{g}$ of penicillin $\mathrm{G}$ per $\mathrm{ml}$ (Rolinson and Stevens, 1961; Sutherland, 1964; Garrod and D'Grady, 1968), and most strains of Proteus mirabilis are sensitive to $5-10 \mu \mathrm{g} / \mathrm{ml}$ (Barber and Waterworth, 1964).

The position of nitrofurantoin, nalidixic acid, and cycloserine (none of which achieves bacteristatic levels in the serum) as established urinary antibiotics (Carroll, 1963; Stamey, Govan, and Palmer, 1965; Murdoch, Speirs, Geddes, Wright, and Received for publication 20 May 1971.
Wallace, 1968) suggests that oral penicillin $G$, which is cheap and not toxic, may be a useful urinary antibiotic if it is confirmed that adequate urine levels are attained.

\section{Materials and Methods}

SUBJECTS AND PENICILLINS

Six healthy subjects (aged 17-28 years) took part in the experiment. Each drug was taken about $30 \mathrm{~min}$ before breakfast after the bladder had been emptied. There were no restrictions on fluid intake. At least one day elapsed before the experiment was repeated by each subject with another drug.

\section{Potassium penicillin $G$ (Crystapen $G$ )}

Two $250 \mathrm{mg}$ sugar-coated tablets were taken.

\section{Sustained action penicillin $G$ (Hyasorb)}

This enteric-coated formulation of penicillin $G$ is presented in $150 \mathrm{mg}$ tablets. The dose was 3 tablets.

\section{Penamicillin (Havapen)}

This acetoxymethyl ester of penicillin $\mathrm{G}$ is hydrolysed to penicillin $G$ in the body. The dose was 2 tablets of $350 \mathrm{mg}$, each tablet containing an equivalent of $305 \mathrm{mg}$ of penicillin.

The manufacturers of Hyasorb (Berk) and Havapen (Wyeth) claim improved absorption resulting in prolonged effective serum levels for their products compared with those achieved with potassium penicillin. The approximate cost of one dose of each drug is: Crystapen G, 2p. Hyasorb, 63p, Havapen, 4p. 
BI ' OD AND URINE LEVELS OF PENICILLIN Two and six hours after the drug was given venous blood was withdrawn, separated, and the serum filtered (Millipore filters, with $0.45 \mu \mathrm{m}$ pores). The bladder was emptied at two, four, six, eight, 12, and 24 hours and the whole of the specimen was collected. The volume of each specimen was recorded and an aliquot filtered. The tests were carried out by a doubling dilution technique (Cruickshank, 1965), the indicator organism being the Oxford (Heatley) strain of Staphylococcus aureus. The range of penicillin concentrations detectable in the serum was $0 \cdot 02-10 \cdot 24 \mu \mathrm{g} / \mathrm{ml}$ and in the urine, which was diluted 100-fold initially, it was $2-2,048 \mu \mathrm{g} / \mathrm{ml}$.

\section{Results}

Table I records the results of the experiment.
Differences of up to eight fold in the concentration of penicillin in the urine between subjects were observed and this may be related in part to the volume of urine excreted. After taking potassium penicillin $G$ the urine levels were remarkably consistent at $512 \mu \mathrm{g} / \mathrm{ml}$ in the first two hours and were well maintained up to the fourth hour, falling away rapidly thereafter. Serum levels of penicillin were about 1,000 times less than the urine levels.

Because of the different amounts of penicillin in the various preparations mean levels from the six subjects were calculated and adjusted to a dose of $500 \mathrm{mg}$ of penicillin (Table II). Potassium penicillin gave the highest initial level, falling off fastest, whereas penamicillin and sustained action penicillin gave lower levels which were better maintained after four hours. The proportion of the various drugs excreted in 24 hours was $13.4 \%$ of potassium peni-

\begin{tabular}{|c|c|c|c|c|c|c|c|c|c|c|}
\hline \multirow[t]{2}{*}{ Drug and Dose } & \multirow[t]{2}{*}{ Subject } & \multicolumn{6}{|c|}{$\begin{array}{l}\text { Level of Penicillin in Urine }(\mu \mathrm{g} / \mathrm{ml}) \text { Collected at Time }(\mathrm{hr}) \\
\text { after Drug Given by Mouth }\end{array}$} & \multirow{2}{*}{$\begin{array}{l}\text { Volume }(\mathrm{ml}) \\
\text { of Urine } \\
\text { Excreted } \\
\text { between } 0 \\
\text { and } 6 \text { Hours }\end{array}$} & \multicolumn{2}{|c|}{$\begin{array}{l}\text { Level of Penicillin in Blood } \\
\text { Serum ( } \mu \text { giml) at Time } \\
\text { (hr) after Drug Given } \\
\text { by Mouth }\end{array}$} \\
\hline & & 2 & 4 & 6 & 8 & 12 & 24 & & 2 & 6 \\
\hline $\begin{array}{l}\text { Potassium } \\
\text { penicillin } \mathrm{G} \\
500 \mathrm{mg}\end{array}$ & $\begin{array}{l}\text { JH } \\
\text { BH } \\
\text { AB } \\
\text { DG } \\
\text { JE } \\
\text { SH }\end{array}$ & $\begin{array}{r}512 \\
512 \\
512 \\
1,024 \\
512 \\
512\end{array}$ & $\begin{array}{r}512 \\
256 \\
128 \\
256 \\
64 \\
128\end{array}$ & $\begin{array}{l}64 \\
32 \\
64 \\
32 \\
32 \\
16\end{array}$ & $\begin{array}{r}16 \\
16 \\
32 \\
8 \\
8 \\
4\end{array}$ & $\begin{array}{l}0 \\
8 \\
8 \\
2 \\
2 \\
0\end{array}$ & $\begin{array}{l}0 \\
0 \\
0 \\
0 \\
0 \\
0\end{array}$ & $\begin{array}{l}400 \\
190 \\
215 \\
255 \\
410 \\
180\end{array}$ & $\begin{array}{l}1.28 \\
0.16 \\
0.64 \\
0.32 \\
0.64 \\
0.32\end{array}$ & $\begin{array}{r}<0.02 \\
0.02 \\
0.04 \\
0.02 \\
0.04 \\
0.04\end{array}$ \\
\hline $\begin{array}{l}\text { Penamecillin } \\
700 \mathrm{mg} \\
\text { equivalent to } \\
610 \mathrm{mg} \\
\text { penicillin } \mathrm{G}\end{array}$ & $\begin{array}{l}\text { JH } \\
\text { BHi } \\
\text { AB } \\
\text { DG } \\
\text { JE } \\
\text { SH }\end{array}$ & $\begin{array}{r}128 \\
1,024 \\
1,024 \\
256 \\
256 \\
512\end{array}$ & $\begin{array}{l}512 \\
256 \\
512 \\
128 \\
128 \\
512\end{array}$ & $\begin{array}{r}64 \\
32 \\
64 \\
16 \\
64 \\
128\end{array}$ & $\begin{array}{l}16 \\
16 \\
32 \\
16 \\
32 \\
32\end{array}$ & $\begin{array}{l}2 \\
8 \\
8 \\
8 \\
8 \\
8 \\
8\end{array}$ & $\begin{array}{l}0 \\
2 \\
4 \\
0 \\
4 \\
2\end{array}$ & $\begin{array}{l}560 \\
165 \\
165 \\
460 \\
440 \\
335\end{array}$ & $\begin{array}{l}0.64 \\
0.64 \\
0.64 \\
0.64 \\
0.64 \\
0.64\end{array}$ & $\begin{array}{l}0.08 \\
0.04 \\
0.04 \\
0.04 \\
0.08 \\
0.04\end{array}$ \\
\hline $\begin{array}{l}\text { Penicillin G } \\
\text { sustained } \\
\text { action } \\
\text { tablets } \\
450 \mathrm{mg}\end{array}$ & $\begin{array}{l}\text { JH } \\
\text { BH } \\
\text { AB } \\
\text { DG } \\
\text { JE } \\
\text { SH }\end{array}$ & $\begin{array}{r}256 \\
512 \\
512 \\
64 \\
64 \\
512\end{array}$ & $\begin{array}{r}128 \\
128 \\
256 \\
128 \\
32 \\
128\end{array}$ & $\begin{array}{r}32 \\
64 \\
64 \\
32 \\
8 \\
64\end{array}$ & $\begin{array}{r}8 \\
8 \\
32 \\
8 \\
2 \\
8\end{array}$ & $\begin{array}{l}2 \\
2 \\
0 \\
2 \\
0 \\
0\end{array}$ & $\begin{array}{l}0 \\
0 \\
0 \\
0 \\
0 \\
0\end{array}$ & $\begin{array}{l}495 \\
200 \\
190 \\
385 \\
580 \\
230\end{array}$ & $\begin{array}{l}1.28 \\
\text { (cont } \\
0.16 \\
0.32 \\
0.16 \\
0.16\end{array}$ & $\begin{array}{l}\quad 0.08 \\
\text { ed) } \\
<0.02 \\
0.04 \\
<0.02 \\
0.02\end{array}$ \\
\hline
\end{tabular}

Table I Levels of penicillin in urine and blood at different times after oral administration of a single dose of one of three preparations of penicillin $G$

\begin{tabular}{|c|c|c|c|c|c|c|c|c|}
\hline \multirow[t]{2}{*}{ Drug } & \multicolumn{6}{|c|}{$\begin{array}{l}\text { Adjusted Mean Level of Penicillin in Urine }(\mu \mathrm{g} / \mathrm{ml}) \text { at Time }(\mathrm{hr}) \text { after Drug } \\
\text { Given }\end{array}$} & \multicolumn{2}{|c|}{$\begin{array}{l}\text { Adjusted Mean Level of } \\
\text { Penicillin in Blood Serum } \\
(\mu g / m l) \text { at Time }(\mathrm{hr}) \text { after } \\
\text { Drug Given }\end{array}$} \\
\hline & 2 & 4 & 6 & 8 & 12 & 24 & 2 & 6 \\
\hline Potassium penicillin $G$ & 597 & 324 & 40 & 14 & 4 & 0 & 0.56 & 0.03 \\
\hline Penamecillin & 437 & 280 & 52 & 21 & 8 & 2 & 0.52 & 0.04 \\
\hline $\begin{array}{l}\text { Sustained action } \\
\text { penicillin } G\end{array}$ & 350 & 150 & 49 & 13 & 1 & 0 & 0.47 & 003 \\
\hline
\end{tabular}

Table II Mean penicillin levels calculated from the results in Table I and adiusted to a $500 \mathrm{mg}$ dose of penicillin given by mouth 
cillin $\mathrm{G}, 14 \cdot 1 \%$ of penamicillin, and $11 \cdot 1 \%$ of the sustained action penicillin.

\section{Discussion}

The concentration of penicillin attainable in the urine following the oral administration of penicillin is clearly in excess of the mean inhibitory concentration of most urinary pathogens. After a dose of $500 \mathrm{mg}$ of penicillin by mouth it is probable that the concentration of penicillin in the ureteric urine exceeds $50 \mu \mathrm{g} / \mathrm{ml}$ for at least four hours with peak concentrations of over $1,000 \mu \mathrm{g} / \mathrm{ml}$, and if bladder voiding and administration of the antibiotic were synchronized a concentration of penicillin in excess of $150 \mu \mathrm{g} / \mathrm{ml}$ in the bladder could be maintained for six hours or more. The differences between the three preparations of penicillin tested were not significant therapeutically, but Crystapen $\mathrm{G}$ was the most costeffective.

The relative importance of serum and urine levels of antibiotic in the treatment of pyelonephritis is the subject of debate (Stamey et al, 1965; Cockett, Roberts, and Moore, 1966). In an effort to resolve this Stamey has presented data on 15 patients who were investigated in detail and were treated with oral penicillin or nitrofurantoin. Seven patients had radiological abnormalities, and all had over $10^{5}$ bacteria per $\mathrm{ml}$ of urine that had been collected either by suprapubic bladder puncture (seven cases) or from the ureter at cystoscopy (eight cases). Four patients were given penicillin G $250 \mathrm{mg}$ six hourly, eight had penicillin V $250 \mathrm{mg}$ six hoully, and three were treated with nitrofurantoin $100 \mathrm{mg}$ six hourly. While none could have had serum levels in excess of the mean inhibitory concentration of the infecting organism, all but two were cured. Of these two, one who was treated with nitrofurantoin had a renal stone, and the other (treated with penicillin G) was later shown to have a large residual volume and recurrent infections associated with sexual intercourse.

The results of these experiments establish the urinary concentrations of penicillin which can be achieved with oral therapy, and form a base upon which the use of penicillin for urinary infection may be founded.

\section{References}

Barber, M., and Waterworth, P. M. (1964). Antibiotic sensitivity o Proteus species. J. clin. Path., 17, 69-74.

Carroll, G. (1963). Neggram (nalidixic acid): a new antimicrobial chemotherapeutic agent. J. Urol., 90, 476-480.

Cockett, A. T. K., Roberts, A. P., and Moore, R. (1966). Significance of antibacterial levels in renal lymph during treatment for pyelonephritis. J. Urol., 95, 164-168.

Cruickshank, R. (1969). Medical Microbiology, 11 th ed., p. 901. Livingstone, Edinburgh.

Finland, M., Meads, M., and Ory, E. M. (1945). Oral penicillin. $J$. Amer. med. Ass., 129, 315-320.

Garrod, L. P., and O'Grady, F. (1968). Antibiotic and Chemotherapy, 2nd ed., p. 361. Livingstone, Edinburgh.

McDermott, W., Bunn, P. A., Benoit, M., DuBois, R., and Reynolds, M. E. (1946). The absorption, excretion and destruction of orally administered penicillin. J. clin. Invest., 25, 190-210.

Murdoch, J. McC., Speirs, C. F., Geddes, A. M., Wright, N., and Wallace, E. T. (1968). Treatment of recurrent urinary tract infection. In Urinary Tract Infection, edited by F. O'Grady and W. Brumfitt, pp. 227-234. Oxford University Press, London.

Peeney, A. L. P. (1947). Discussion of the use of penicillin in urology. Proc. roy. Soc. Med., 40, 433-442.

Rolinson, G. N., and Stevens, S. (1961). Microbiological studies on a new broad spectrum penicillin, 'Penbritin'. Brit. med. J., 2, 191-196.

Stamey, T. A., Govan, D. E., and Palmer, J. M. (1965). The localisation and treatment of urinary tract infections: the role of bactericidal urine levels as opposed to serum levels. Medicine (Baltimore), 44, 1-36.

Sutherland, R. (1964). The nature of the insensitivity of Gramnegative bacteria towards penicillins. J. gen. Microbiol., 34, 85-98.

Wright, W. W., Kirshbaum, A., Arret, B., Putnam, L. E., and Welch, H. (1955). Serum concentrations and urinary excretion following oral administration of penicillin $\mathbf{V}$ and comparison with penicillin G. Antibiot. Med.. 1, 490-495. 